
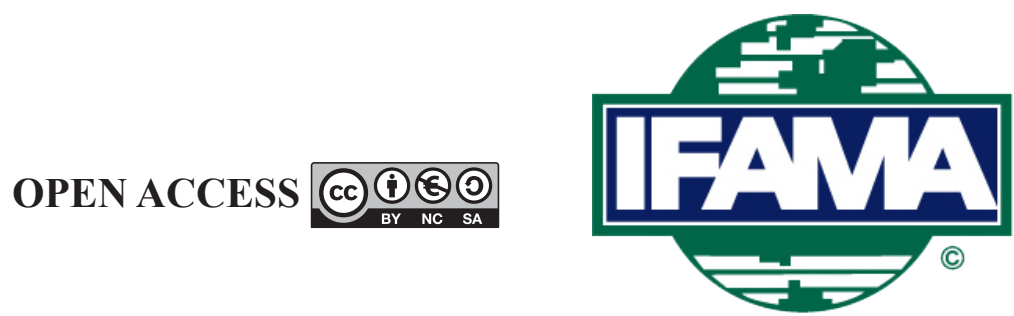

International Food and Agribusiness Management Review

Volume 24, Issue 2, 2021; DOI: 10.22434/IFAMR2020.0046

Received: 26 March 2020 / Accepted: 17 October 2020

\title{
Discounted cash flow valuation of conventional and cage-free production investments
}

\author{
Carlos J.O. Trejo-Pech ${ }^{\oplus}$ and Jada M. Thompson \\ Assistant Professor, Department of Agricultural and Resource Economics, \\ University of Tennessee, 2621 Morgan Circle, Knoxville, TN 37996, USA
}

\begin{abstract}
This study compares profitability and risk of conventional and cage-free egg production in the United States. Evaluating cage-free production is particularly relevant given ongoing consumer driven changes and new cage-free legislation. Results show that while the Modified Internal Rate of Return (MIRR) for conventional production is above an estimated industry opportunity cost of capital, cage-free production's MIRR does not fully satisfy investors' expectations. The MIRR of cage-free investment, between $5.6 \%$ (deterministic model) and $8.0 \%$ (stochastic) per 15 -month flock, is below the $9.4 \%$ opportunity cost of capital. In addition, the simulations show that there is a $90 \%$ probability of conventional production's MIRR falling between 18.5 and $20.3 \%$ per 15 -month flock, and cage-free egg production's MIRR ranging from 6.8 to 9.4\%. In order for cage-free to be as equally profitable as conventional production, cage-free egg prices at the farmer gate should be $74 \%$ over conventional egg prices. Such high cage-free egg prices are highly unlikely to occur given recent cage-free price premia and consumer willingness to pay estimates from recent research. This study provides a framework egg producers can use to evaluate the potential effects of changes in their portfolio of products (i.e. conventional and cage-free mix) as they accommodate production schedules in this evolving industry.
\end{abstract}

Keywords: discounted cash flow valuation, stochastic simulation, financial modeling, cage-free egg production JEL code: G11, G21, G31, G32

\footnotetext{
(i)Corresponding author: ctrejope@utk.edu
} 


\section{Introduction}

Egg production in the United States (US) is concentrated in the Midwest, Southeast, and California (USDANASS, 2019). As of the end of 2019 , about $80 \%$ of table egg laying chickens are produced under cage systems (conventional production, hereafter) with the remaining $20 \%$ produced as specialty eggs, with cagefree being by far the prevalent specialty eggs category (Egg Industry Center, 2019). Cage-free production, however, has been growing rapidly in recent years. Data compiled by the Egg Industry Center show that the cage-free layer flock relative to the total US flock grew gradually from around 5\% in 2009 to $11 \%$ in 2017, with an accelerated growth after that year, reaching 20\% in 2019 (Egg Industry Center, 2019). This growth has been motivated in part by new laws aiming to protect animal welfare. California voters passed the Proposition 2 regulation in 2008, which later provided specific rules and was enforced starting January 2015. Proposition 2 added constraints to conventional production by requiring that eggs sold in California come from chickens that were provided enough room to turn around and fully extend their wings. Policy restricting farm animal housing is controversial because it has the potential to economically harm production and consumption. Lusk and Norwood (2011) argue that to remain in business, producers face incentives to adopt profit maximization production systems, and that profit-maximizing outcomes are not the same as animal welfare-maximizing outcomes. Indeed, Mullally and Lusk (2018) estimated that the implementation of Proposition 2 caused California consumers to experience annual welfare losses of at least $\$ 25$ million from higher egg prices alone in the years following the policy, and they recognize this estimate to be conservative. They estimated that egg production in California fell by $35 \%$ and egg prices increased, on average, by $22 \%$ two years after its implementation in 2015.

Recently, on November 6, 2018, California voters approved the Prevention of Cruelty to Farm Animals Act, also known as Proposition 12, a new policy further restricting farm animal housing production. Proposition 12 advanced Proposition 2 by requiring all eggs sold in California to be produced from cage-free hens by 2022. This new policy provides specific housing production size requirements and extends these requirements to out-of-state farmers selling eggs to California (Keller and Heckman LLC, 2018). California is a top ten egg producing state in the country, and was the first to legislate production practices to protect hens' welfare. However, other states, including Massachusetts, Michigan, Ohio, Oregon, and Washington, have already passed laws that will eventually limit the use of conventional eggs production (Mullally and Lusk, 2018). In August 2019, Oregon passed a law similar to California's Proposition 12 by requiring all eggs produced and sold in this state to come from cage-free production by 2024. This study compares the financials of conventional and cage-free egg production at the farm level without evaluating the effects of cage-free policies in a particular state. The study rather assumes that the ongoing state-level cage-free policies have the potential to structurally change the US egg industry by changing profitability and risk profiles of farm producers. Besides cage-free regulations, actions by major food buyers toward cage-free eggs suggest that the share of cage-free egg production will continue growing in the US.

Major food buyers such as McDonald's, Target, Walmart and Whole Foods and a long list of restaurants and distributors have expressed intentions to only sell cage-free eggs in the mid-term (Bovay and Summer, 2019; Morris, 2016; Pershan, 2018). Cal-Maine Foods Inc., the largest egg producer in the US, with estimated 15\% market share (Madigan, 2019), informed in its 2019 Annual Report to shareholders that some of its major customers, including food service providers, national restaurant chains, and major retailers, have already stated future dates to exclusively purchase cage-free eggs (Cal-Maine Foods, 2019b).

Transitioning from conventional to cage-free production is expensive. Establishing a cage-free system requires additional investments to conform to cage-free laws, increases operational costs due to changes in production practices, and increases marketing risk by making more uncertain demand and price prediction. All this will cause significant changes to egg production in the US. As an example, Cal-Maine Foods Inc., foreseeing industry changes, filed an $8 \mathrm{~K}$ report of 'unscheduled material events or corporate event' with the Securities Exchange Commission on January 4, 2019, in regards to Proposition 12. The 8K report states: 'We are closely monitoring industry developments surrounding the recent passing of Proposition 12 in California... While 
this referendum will clearly affect sourcing and production of eggs in California, we also expect it to affect future supply and pricing in other areas of the country... Cal-Maine Foods is well positioned to capitalize on this opportunity to expand our operations or consider potential acquisitions' (Cal-Maine Foods, 2019a: 1).

This study evaluates financial models of conventional and cage-free egg production systems in the US. Evaluating profit and risk profiles of these production systems should provide insights on how poultry producers may adjust their production schedules and how they will be affected as the industry moves further towards cage-free. Early industry studies on the effects of potential law restricting hens housing concluded that the relatively high cost of converting conventional systems to more friendly hen production systems was a barrier for the implementation of such laws (Agralytica Consulting, 2012; Promar International, 2009; Summer et al., 2011). Others questioned consumers' willingness to pay the premium that would be required given high conversion costs (Lusk, 2019; Summer et al., 2011; Welshans, 2018). More recently, Matthews and Summer (2015) documented the first systematic comparison of investment and operating costs across egg housing systems by one US commercial farm using the same management and accounting practices. The study, conducted during two flocks of production in a Midwestern US commercial farm, reported that average total production cost per flock in a cage-free system is $36 \%$ higher relative to a conventional system (CSES, 2015; Matthews and Sumner, 2015).

Our study builds on the analysis by Matthews and Summer (2015) on several ways. We estimate and update certain items from the budget, notably - but not only, feed cost, which represents the largest production cost item. Matthews and Summer's study was conducted during two laying flocks grown in 2010/2011, when commodity prices that are part of the poultry feed ration were extraordinarily high relative to current and projected prices. In addition to updating egg production budgets, we apply discounted cash flow (DCF) to value conventional and cage-free enterprises. DCF provides a rate of return over a long-term business horizon, which is needed to evaluate profitability of a poultry investment. Our DCF model use investment and operating costs updated from Matthews and Summer (2015), 2020-2029 forecasted conventional egg prices by USDA Office of the Chief Economist (2020), and price premium projections for cage-free based on recent historical gap prices between cage-free and conventional egg prices, compiled from the Egg Industry Center (EIC) (Ibarburu, 2019). Profitability for each, conventional and cage-free, investment is compared to an estimated opportunity cost of capital. As a proxy for the egg industry cost of capital we estimate the weighted average cost of capital of Cal-Maine Foods Inc. Finally, we apply stochastic simulation to incorporate uncertainty to the analysis. Our estimations are presumably for a representative medium-sized poultry farm that sells either conventional or cage-free eggs. Overall, our findings indicate that the rate of return of conventional production is above an estimated industry opportunity cost of capital. In contrast, simulated rates of return of cage-free production would not fully satisfy investors' expectations at the estimated opportunity cost. The rate of return of cage-free investment, between 5.6\% (deterministic model) and 8.0\% (stochastic) per 15-month flock, is below the estimated $9.4 \%$ opportunity cost of capital. Results from this study might be informative for both industry stakeholders and the government when considering incentives for farmers and customers to transition to a costlier cage-free eggs system. Management in similar enterprises may find results of this study insightful as they decide how to adjust their portfolios of conventional and cage-free products as the cage-free market continues to grow.

\section{Economic framework}

A poultry farm invests capital into land, housing, and equipment with hopes of future revenue being produced that cover all production costs and at least an expected opportunity cost of capital. DCF valuation provides a framework to value such investment. DCF is commonly used by financial analysts to forecast stock prices and was recently applied in poultry valuation (Bir et al., 2018). The two main inputs of DCF are forecasted free cash flow (FCF) and an estimated opportunity cost of capital, with the output being profitability and risk metrics. FCF is the incremental cash flow attributable to each production system accruing to equity and debt holders and is computed according to Brigham and Houston (2019). FCFs are estimated for each production system and laying flock or production cycle (flock, hereafter) by: 


$$
F C F_{i, f}=N O P A T_{i, f}+D E P_{i, f}-C A P E X_{i, f}-N O W C_{i, f}
$$

where $F C F_{i, f}$ is projected free cash flow for production system $i$ (conventional and cage-free) in flock $f(f=1$, $2, \ldots, 8)$. We forecasted FCF for eight 15 -month flocks as the investment horizon. ${ }^{1}$ NOPAT is net operating income after taxes, computed as revenues minus all cash and non-cash operating costs ${ }^{2}$ minus income taxes; DEP is depreciation expenses; and CAPEX is capital expenditures, defined as investments in fixed assets. Investment in net operating working capital (NOWC) is assumed zero in this analysis.

The FCF series for each production system are used to calculate the Modified Internal Rate of Return (MIRR), a rate of return expressed on a per flock basis in this application. The MIRR is the profitability rate that would satisfy return expectations of both debt holders and shareholders if it is at least equal to an expected risk-adjusted opportunity cost of capital. ${ }^{3}$

MIRR is calculated as:

$$
M I R R=\left(\frac{F V_{F}^{+}}{P V_{0}^{-}}\right)^{\frac{1}{F}}-1,
$$

where $\mathrm{FV}_{F}{ }^{+}$is the future value at time $F=8$, the end of the eighth flock, of all positive FCFs composed at the opportunity cost of capital; and $P V_{0}^{-}$is the absolute value of the present value at time zero of all negative FCF discounted at the opportunity cost of capital. In this application, $P V_{0}^{-}$equals the initial capital expenditures or CAPEX from Equation 1.

The MIRR estimation requires an opportunity cost of capital to account for the time value of money (i.e. to compose and discount cash flows) and risk. According to surveys, most firms in the US use the weighted average cost of capital (WACC), a risk-adjusted rate of return, as the discount rate for DCF valuation (Jagannathan et al., 2016). We estimated WACC of Cal-Maine Foods Inc., a publicly traded firm specializing in egg production and marketing, and used it as reference for the opportunity cost of capital in this industry. Our approach has advantages and drawbacks. The most relevant advantage of using data from a publicly traded firm (e.g. with observable stock prices) is that we can measure the firm's systematic risk, which captures the firm's risk as priced by investors. A drawback is that Cal-Maine Foods Inc. may be too large to represent the industry.

WACC is estimated as follows:

$$
W A C C=D / C \times r_{D} \times(1-t x)+E / C \times r_{E},
$$

Where $D$ is short-term plus long-term debt; $E$ is the market value of equity; $C$ is capital $=D+E ; r_{D}$ is the annual cost of debt, $r_{E}$ is the cost of equity (discussed later in Section 3.4); and $t x$ is the effective income tax rate.

\section{Data and model estimations}

In this section, we first explain how the FCF components i.e. investment, costs, and revenue are estimated for the deterministic models. Table 1 summarizes the variables. Then, we explain how the discount rate, WACC, is estimated and the stochastic simulation is performed. The facilities are assumed to operate eight 15-month flocks from 2020 to 2029. Supplementary Table S1 shows a timeline of planned activities.

\footnotetext{
${ }^{1}$ The active lifecycle of each flock in the production experiment by Matthews and Summer (2015) was 60 weeks or about 15 months, including one week for transitioning to the next flock. Eight 15-month flocks is equivalent to 10 years, the investment horizon assumption in Bir et al. (2018).

${ }^{2}$ Depreciation expenses are the non-cash operating costs included in this valuation.

${ }^{3}$ The MIRR has been used in agricultural enterprise valuations and has been argued to be a superior metric relative to the traditional Internal Rate of Return (Kierulff, 2008; Trejo-Pech et al., 2018). The MIRR provides results consistent with other DCF metrics that account for the time value of money such as the Net Present Value and the Profitability Index.
} 


\subsection{Capital investments}

CAPEX includes investments in land, house and equipment. The conventional housing plus equipment system in Matthews and Summer (2015) are expressed in 2011 dollars. We re-expressed CAPEX values as of the end of 2019 according to the Consumer Price Index (CPI) (U.S. Department of Labor, Bureau of Labor Statistics, 2020). CAPEX values, in Table 1, are comparable to current market values according to industry pricing elicited from equipment suppliers. Several telephone contacts were made with various equipment industry participants in order to verify that CAPEX estimates are realistic. The conventional egg layer house has the capacity to handle up to 196,680 birds with 80 square inches per bird and the cage-free house could hold up to 50,000 birds at 144 square inches per bird, a density complying with Proposition 12 (United Egg Producers, 2017). Details on these hen houses are provided in the Coalition for Sustainable Egg Supply research report (CSES, 2015) and in Matthews and Summer (2015).

\subsection{Operating costs and other costs}

Cost categories in the poultry enterprise include: (1) pullets (immature female chickens); (2) feed; (3) labor; (4) depreciation; and (5) energy and others.

\section{- Pullets}

Total cost of 19-week old pullets per flock and production type is estimated ${ }^{4}$ as:

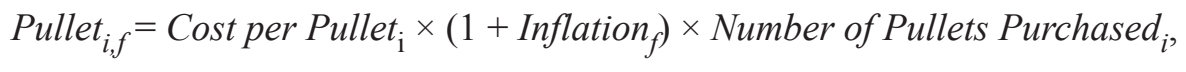

where 'Pullet' is the total pullet cost per 15 -month flock for production system $i(i=1,2)$ in flock $f(f=1,2$, $\ldots, 8)$, and is calculated as a function of the price of pullets and the number of pullets purchased. 'Cost per Pullet' is the pullet cost for the first flock. Pullet costs for subsequent flocks are updated using forecasted inflation rates. The 'Number of Pullets Purchased' varies by production system due to space restrictions and is the same each flock (Table 1).

For the first flock, the pullet cost for conventional production is estimated in $\$ 3.80$, the national average of 2018 and 2019 monthly pullet prices compiled from the EIC (Ibarburu, 2017, 2019). Pullets for cage-free production need to be acculturated to such system, and are therefore reared in a cage-free rearing barn, which is assumed to be $41 \%$ more expensive than conventional rearing due to higher space requirements and feed consumption (Matthews and Sumner, 2015).

- Feed

Total feed cost per flock and production type is estimated as follows:

$$
\begin{aligned}
& \text { Feed }_{i, f}=\text { Feed Unit Cost }_{f} \times \text { Feed Consumption }_{i} \times{\text { Number of Pullets } \text { Purchased }_{i}} \times\left(1-\left(\text { Mortality }_{i} / 2\right)\right),
\end{aligned}
$$

where 'Feed' is the total cost of feed per 15-month flock for production system $i$ in flock $f$; 'Feed Unit Cost' is the projected price per pound of feed in flock $f$; 'Feed Consumption' is the estimated feed consumed per bird through the 15-month flock by production system; 'Mortality' is the proportion of birds placed on farm that die throughout the flock cycle and is divided in half to account for the feed consumed by those birds prior to death assuming that on average birds die halfway through the flock cycle; and 'Number of Pullets Purchased' is previously defined.

\footnotetext{
${ }^{4}$ Notice that in Equation 4, and in the equations that follow, variables either have one or both $i$ and $f$ subscripts. If a variable has only subscript $i(f)$ is because it varies by production system (flock) but it does not change per flock (production system).
} 
Table 1. Parameters for the free cash flow estimations.

\begin{tabular}{|c|c|c|c|c|c|}
\hline \multirow[b]{2}{*}{ Variable name } & \multirow[b]{2}{*}{ Units } & \multicolumn{2}{|l|}{ First flock } & \multirow{2}{*}{$\begin{array}{l}\text { Subsequent flocks } \\
\text { Conventional and cage free }\end{array}$} & \multirow[b]{2}{*}{ Stochastic } \\
\hline & & Conventional & Cage-free & & \\
\hline CAPEX $^{1}$ & $\$$ & $3,381,956$ & $2,231,863$ & No additional investment & \\
\hline Number of pullets purchased ${ }^{2}$ & Birds per flock & 196,128 & 49,760 & Remain the same & \\
\hline Cost per pullet ${ }^{3}$ & \$ per pullet & 3.80 & 5.36 & Vary with inflation & \\
\hline Feed unit cost ${ }^{4}$ & $\$$ per pound & 0.095 & 0.095 & Forecasted each flock & yes \\
\hline Feed consumption ${ }^{5}$ & Pounds per bird & 108.33 & 111.13 & Remain the same & \\
\hline Mortality $^{2}$ & $\%$ per flock & 4.8 & 13.3 & Remain the same & yes \\
\hline Labor unit cost ${ }^{6}$ & \$ per dozen eggs & 0.022 & 0.084 & Vary with inflation & \\
\hline Eggs produced ${ }^{2}$ & Dozen per flock & $5,928,337$ & $1,423,795$ & Remain the same & \\
\hline Dep $^{7}$ & \$ per flock & 419,898 & 277,560 & Remain at historical book values & \\
\hline Energy $^{6}$ & \$ per dozen eggs & 0.022 & 0.023 & Vary with inflation & \\
\hline Other costs ${ }^{8}$ & \$ per dozen eggs & 0.067 & 0.067 & Vary with inflation & \\
\hline Egg price $^{9}$ & \$ per dozen & 0.854 & 1.025 & USDA forecast & yes \\
\hline Non-marketable eggs rate ${ }^{10}$ & $\%$ per flock & 2.0 & 10.0 & Remain the same & \\
\hline Income tax rate ${ }^{11}$ & $\begin{array}{l}\% \text { of taxable } \\
\text { income }\end{array}$ & 27.0 & 27.0 & Remain the same & \\
\hline
\end{tabular}

${ }^{1}$ CAPEX values in Matthews and Summer (2015) were re-expressed as of the end of 2019 according to the Consumer Price Index (U.S. Department of Labor, Bureau of Labor Statistics, 2020). No residual value is assumed.

${ }^{2}$ Number of pullets, mortality, and eggs produced are parameters in Matthews and Summer (2015).

${ }^{3}$ Cost per pullet for conventional production is the national average of 2018 and 2019 monthly pullet costs (Ibarburu, 2017, 2019). Pullets for cage-free is $41 \%$ more expensive than conventional pullets (Matthews and Sumner, 2015).

${ }^{4}$ Feed unit costs (\$ per pound) were estimated for a typical layer feed ration using commodity prices, transportation, milling costs, and inflation rates forecasted by the USDA, Office of the Chief Economist (2020) and the EIC (Ibarburu, 2019). The feed ration has $67 \%$ corn, $22 \%$ soybean meal, $8 \%$ calcium, and 3\% other ingredients. Table 1 shows costs for the first flock only. Forecasted feed cost for flocks two through eight are 0.091, 0.091, 0.092, 0.094, 0.096, 0.097, and 0.098.

${ }^{5}$ For conventional production, estimated feed consumption per hen through the 15 -month flock is the national average reported by the EIC, calculated by multiplying 3.14 pounds per dozen eggs times 34.5 dozen eggs (Ibarburu, 2019). For cage-free, feed consumption is $2.6 \%$ higher (Matthews and Sumner, 2015).

${ }^{6}$ Labor unit cost and energy cost are parameters in Matthews and Summer (2015) re-expressed as of the end of the first flock according to the CPI and projected inflation rates.

${ }^{7}$ Straight depreciation system schedule for plant and equipment (Bir et al., 2018).

${ }^{8}$ Other costs are estimated in reference to the December 2019 EIC Cost and Price Report (https://www.eggindustrycenter.org/browse/ files/dc4a8a9a215c4ff3bcd19d3bbb506ffc/view). Other costs, in the EIC report, equal \$0.180 per dozen eggs (e.g. total cost minus pullet cost minus feed cost). To this value, we subtracted our cost estimates for labor, energy, and depreciation, which are undisclosed in the EIC Report (0.180-0.022-0.022-0.071) and applied projected inflation as of the end of the first flock.

${ }^{9}$ Egg prices for conventional production are forecasts by USDA Office of the Chief Economist (2020). Since prices are forecasted on a yearly basis, we adapted them on a per flock basis. For instance, forecasted prices are $\$ 0.850$ for 2020 and $\$ 0.869$ for 2021 . Since the first flock ends in March 2021 (Supplementary Table S1), price for the first flock $=\$ 0.850 \times(12 / 15)+\$ 0.850 \times(3 / 15)=$ $\$ 0.854$. Prices for subsequent flocks are calculated similarly following the timeline in Supplementary Table S1. Conventional egg prices for flock two through eight are $0.869,0.874,0.891,0.905,0.915,0.925$ and 0.935 . Cage-free prices have a $20 \%$ premium over conventional egg prices, the average of the monthly price premium paid for cage-free egg over conventional egg during two 15-month flocks from 2017 to 2020 (Ibarburu, 2017, 2019).

${ }^{10}$ Non-marketable eggs rates according to Summer et al. (2008).

${ }^{11}$ Projected tax rate according to KPMG (2018). 
We estimated feed unit costs (\$ per pound) in each flock for a typical layer feed ration using forecasted commodity prices and inflation rates as in Ibarburu and Bell (2014). The feed ration has 67\% corn, 22\% soybean meal, $8 \%$ calcium, and 3\% other ingredients. Corn and soybean meal prices are yearly forecasts by the USDA, Office of the Chief Economist (2020). Calcium, other ingredients, and transportation and milling costs are estimates by the EIC (Ibarburu, 2019) updated by forecasted inflation. ${ }^{5}$

For conventional production, estimated feed consumption per hen (pounds per bird) is 108.33 pounds through the 15-month flock, the national average reported by the EIC (Ibarburu, 2019). Feed consumption of hens for cage-free is slightly higher than under conventional production, consistent with the literature which shows reduced feeding efficiency in cage-free production (Aerni et al., 2005; Karcher et al., 2015). We incorporate the 2.6\% feed cost difference reported in Matthews and Summer (2015) as the difference in feed consumption among production systems.

Equation 5 has a mortality rate incorporated, which is $4.8 \%$ for conventional production and $13.3 \%$ for cage-free (Matthews and Sumner, 2015). Previous research have consistently reported higher mortality rates in cage-free enterprises (CSES, 2015; Elson, 2008; Rodenburg et al., 2008; Sumner et al., 2008; Weeks et $a l ., 2012)$. The difference and increased variation in mortality rates between conventional and cage-free production are driven by increased injury, infectious diseases, and cannibalization. Increases in access to fecal contaminated water and food is a concern in cage-free production which leads to increases morbidity and mortality (Burch, 2012; Fossum et al., 2009).

- Labor

Total labor cost (Labor) is estimated as:

$$
\text { Labor }_{i, f}=\text { Labor Unit Cost }_{i} \times\left(1+\text { Inflation }_{f}\right) \times \text { Eggs }_{\text {Produced }} \text {, }
$$

where 'Labor Unit Cost' (\$ per dozen eggs produced) for cage-free is 3.89 times higher than conventional production labor unit cost, the latter estimated in $\$ 0.021$ per dozen eggs (Matthews and Sumner, 2015). The cage-free additional labor accounts for increased demands for walking the flocks, gathering and washing eggs, and additional management not required in conventional production. Previous research has documented labor cost differences between production systems (Bell and Weaver, 2002; Van Staaveren et al., 2018). Total egg production per flock is assumed to be 5,928,337 dozen eggs for the conventional system and 1,423,795 dozen for cage-free (Matthews and Sumner, 2015).

\section{- Depreciation}

Depreciable assets are expended equally during eight 15-month flocks, equivalent to ten years (Bir et al., 2018), according to a straight depreciation system schedule.

\section{- Other costs}

The budgets include energy and other costs. Other costs are estimated in reference to the December 2019 EIC Cost and Price Report (details in Table 1). Manure cleaning cost is not budgeted, assuming that this cost equals manure revenue. This assumption accounts for regional differences in manure application, legal and environmental regulations, and markets for manure. Both conventional and cage-free houses are assumed to use similar belt-driven manure management systems that lead to a storage lagoon, limiting differences in manure management costs.

\footnotetext{
${ }^{5}$ Commodity prices are forecasted on a yearly basis and all the values in this budget are expressed on a 15 -month flock basis. Adjustments were made for feed costs, inflation rates, and egg prices following the procedure explained in table 1 for egg prices.
} 


\section{- Inflation rates}

Forecast inflation rates in the model are from the USDA Office of the Chief Economist (2020). ${ }^{6}$

\section{- Tax rates}

Assumed income tax rate is $27 \%$, including federal and local taxes, according to KPMG International Cooperative's estimate for 2018 US corporate tax rate, which has the effects of the Tax Cut and Jobs Act of 2017 (KPMG, 2018).

\subsection{Revenue}

Total revenue by production system $i$ in flock $f$ is computed as:

$$
\text { Revenue }_{i, f}=\text { Egg }_{\text {Price }}, \text { Eggs }_{i, f} \text { Produced }_{i} \times\left(1-\text { Non Marketable Eggs Rate }_{i}\right)
$$

where egg prices for conventional production are long-term forecasted prices at the farm gate by USDA Office of the Chief Economist (2020). Since USDA forecast prices are provided on a yearly basis, we adapted them on a per flock basis for this analysis (details provided in Table 1). Cage-free egg prices are conventional egg prices plus a $20 \%$ price premium, which is the average of the monthly price premium paid for cage-free egg over conventional egg during two 15 -month flocks from 2017 to $2020 .^{7}$ Total dozen eggs produced per production system (Table 1) have already incorporate the 4.8 and 13.3\% mortality rate assumptions for conventional and cage-free production. A change in mortality rates from the baseline model will therefore affect revenue (and operating costs); such a scenario is also simulated in this study and explained later. Revenue is also affected by a percentage of non-marketable eggs, which has been reported in the literature to be higher for cage-free production due to increases in floor eggs or excessively dirty eggs which are removed from the supply chain (Holt et al., 2011). Using Summer et al. (2008), 2 and 10\% unmarketable eggs are used for conventional and cage-free.

Table 1 summarizes parameters for the FCF estimation (Equation 1). These values are the deterministic values associated with a representative producer for conventional and cage-free. The stochastic models allow for variability in these values in estimating the financial situation of egg laying production. Inputs to estimate the discount rate, Equation 3, are discussed next.

\subsection{Weighted average cost of capital}

By the end of the 2019 fiscal year, Cal-Maine Foods Inc. did not have any debt (S\&P Capital IQ, 2020), which reduces WACC, Equation 3, to the cost of equity. The cost of equity, $r_{E}$ in Equation 3, is estimated using the Capital Asset Pricing Model (Sharpe, 1964), $r_{E}=r f+\beta \times M R P$, where $r f$ is the risk-free rate, proxied by the average of the 2019 daily US Treasury Bonds' composite long-term rates $=2.5 \%$ (US Department of the Treasury, 2020); MRP the market risk premium, the difference of historical average stock market return and risk-free rate, is 9.3\% (Graham and Harvey, 2018); and $\beta$, Cal-Maine's systematic risk factor, is the 5-year beta estimated using daily prices for Cal-Maine and the S\&P 500 index, equal to 0.50 . Given that Cal-Maine's leverage was zero, we re-levered Cal-Maine's beta assuming a 40\% debt and 60\% equity for the poultry producer featured in this paper using the Hamada equation (Schill, 2017). The debt/equity mix assumed is rather arbitrary since we lacked for a reference in the poultry industry, but is reasonable for an average agribusiness firm (Trejo-Pech et al., 2016).

\footnotetext{
${ }^{6}$ Yearly inflation rates were adjusted to 15 -month flock. Refer to the previous footnote.

${ }^{7}$ Cage-free prices are available starting the end of 2016. We constructed a series of prices comprising two 15-month laying flock production cycles (January 2017 to March 2018 and January 2019 to March 2020) of cage-free egg prices (large eggs, negotiated loose) and conventional (large eggs) from the USDA Agricultural Marketing Service monthly reports (Egg Industry Center, 2020; USDA-AMS, 2020a) and calculated the percentage difference.
} 


\subsection{Stochastic discounted cash flow valuation}

Uncertainty was incorporated into the DCF valuation by performing stochastic simulation with @RISK® (Palisade, 2018). FCFs were made stochastic by assuming probability distributions for the following variables: (1) conventional egg prices; (2) feed unit cost; (3) cage-free egg price premium; and (4) mortality rates per production system. The last column in Table 1 indicates the stochastic variables. Profitability is highly sensitive to these variables, e.g. prices and mortality rates directly affect revenue, and feed cost represents slightly above a half of total costs.

We assume that the stochastic variables follow a PERT distribution, a special case of a scaled beta distribution, parameterized with the minimum, most likely, and maximum values according to historical values and industry projections. The PERT distribution is generally more accurate than the triangular distribution, which has been applied in agribusiness to model behavior in new markets or when little data is available (Yeboah et al., 2013). Compared to the triangular distribution, PERT has a smoother curve, and for non-symmetric parameters it tends to have a smaller proportion of values in its tails (Rees, 2015). Other studies using PERT in agriculture include Kenner et al. (2019) in poultry production and Turvey et al. (2013) in crop insurance.

Conventional egg prices have a minimum and maximum values according to the 2020-2029 forecast price series at the farm gate by USDA Office of the Chief Economist (2020), and most likely values varying each flock using the forecast prices from the deterministic model. Cage-free egg price premium simulations assume a minimum value of zero (i.e. cage-free eggs are not sold below conventional prices at the farm level); a most likely cage-free price premium equal to $\$ 0.30$ per dozen eggs, which is the median value of willingness to pay estimates of a national survey of over 2,000 US consumers in Lusk (2019); and a maximum value of $\$ 0.34$ premium per dozen, estimated in reference to the $\$ 0.30$ (most likely value above) observed during the most recent 15 -month flock in a series of monthly prices reported by the USDA-AMS (2020b). ${ }^{8}$ Feed input prices use the min (\$0.314 per dozen eggs produced), max (\$0.370), and median $(\$ 0.326)$ values in a five year feed price series, build by the authors using monthly national feed prices reported by the EIC (2020). The simulations assume an observed correlation coefficient of 0.537 for egg prices and feed costs, and 0.819 for conventional and cage-free prices.

To simulate the mortality rates for birds, using six data points of reported mortality rates in the literature, for each production system (CSES, 2015; Elson, 2008; Matthews and Sumner, 2015; Rodenburg et al., 2008; Sumner et al., 2008; Weeks et al., 2012), we compute the $25^{\text {th }}, 50^{\text {th }}$, and $75^{\text {th }}$ percentiles, and use them as minimum, most likely, and maximum parameters for the simulations.

Stochastic variables were simulated every laying flock during the investment horizon. The simulation was conducted using 10,000 iterations. A fixed simulation seed was used for the two production systems to provide comparable results across models.

\section{Results and discussion}

Costs and prices are discussed in terms of per dozen eggs because it is the standard metric in the layer industry. First, the discussion focuses on cost estimates for the first flock of production, which is assumed to start in 2020. We then discuss profitability metrics for the deterministic DCF model, which incorporates investment, cost and revenue values of eight flocks. Finally, stochastic simulations are discussed.

\footnotetext{
${ }^{8}$ Cage-free prices with ranges (min, max, and average) were only readily available to the authors starting January 2019 (available at: https://usda. library.cornell.edu/concern/publications/rj4304553?locale=en). We assumed a 15-month flock starting January 2019 and ending March 2020.
} 


\subsection{Cost estimates for the first flock}

Table 2 provides cost estimates for the first flock. Estimated total cost per dozen equals $\$ 0.644$ for conventional production and \$0.908 for cage-free. The cost estimate for conventional production is similar to the 2019 estimate by the EIC, $\$ 0.603$ (Ibarburu, 2019). The EIC estimate, however, does not provide enough level of disaggregation for the purposes of the evaluation in this study. The EIC does not estimate cage-free production cost. Our cost estimates are very similar to Cal-Maine Foods Inc.'s farm production costs from 2017 to 2019 , which are on average 0.637 and 0.898 for the firm's non-specialty and specialty egg business segments (Trejo-Pech and White, 2020). This study estimates that cage-free production costs above $41 \%$ more than conventional production in terms of dozen eggs produced.

Cost estimates in this study are lower than Matthews and Summer's (2015), at \$0.773 for conventional production and \$1.052 for cage-free. (Values in Matthews and Summer were re-expressed as of the end of 2019 by the CPI to make them comparable with our estimates.) Our lower estimates relative to Matthews and Summer's (2015) are mainly explained by feed costs, which are estimated at \$0.334 (\$0.346) for conventional (cage-free) compared to $\$ 0.494$ (\$0.507) in Matthews and Summer (2015). Matthews and Summer conducted their field study in 2010/2011, when commodity prices, specifically corn and soybean meal, that are part of the feed ration were higher than current and projected prices. For instance, corn prices were traded at $\$ 6.80$ per bushel in 2011 compared to $\$ 3.70$ in 2019 (Macrotrends, 2019). These exceptionally high prices were related to increased demand for bioethanol due to government subsidies as well as other production and market factors. The demand for corn subsequently caused changes in planting patterns leading to increased prices for most commodities due to limited supply, even with modified feed rations. Besides the layer feed implications, pullet costs are also directly impacted by commodity prices since pullets are fed for 19 weeks before purchased for laying purposes. Our lower than Matthews and Summer's (2015) pullet costs reflect this commodity price differences.

Costs provided in Table 2 are those related to the first production flock only. Costs (and prices) for the subsequent seven flocks in the business horizon vary every year as a function of feed cost, output prices, and inflation rates (Table 1). Financial outputs evaluating the complete eight, 15-month flocks are provided in Table 3.

Table 2. Unit cost estimation for the first flock of egg production (\$ per dozen eggs). ${ }^{1}$

\begin{tabular}{|c|c|c|c|c|}
\hline Item & Conventional & Cage-free & Diff. (\$) & Diff. (\%) \\
\hline Pullet $^{2}$ & 0.128 & 0.191 & 0.063 & $49 \%$ \\
\hline Feed $^{3}$ & 0.334 & 0.346 & 0.012 & $4 \%$ \\
\hline Depreciation $^{4}$ & 0.071 & 0.195 & 0.124 & $175 \%$ \\
\hline Labor $^{5}$ & 0.022 & 0.086 & 0.064 & $289 \%$ \\
\hline Energy ${ }^{4}$ & 0.022 & 0.023 & 0.001 & $5 \%$ \\
\hline Other $^{4}$ & 0.067 & 0.067 & 0.000 & $0 \%$ \\
\hline Total cost & 0.644 & 0.908 & 0.264 & $41 \%$ \\
\hline
\end{tabular}

${ }^{1}$ Cost estimates for the first flock, assumed to start production in 2020.

2 Calculated with Equation 4.

${ }^{3}$ Calculated with Equation 5.

${ }^{4}$ Refer to Section 3.2. or Table 1.

${ }^{5}$ Calculated with Equation 6. 
Table 3. Selected financial outputs for the deterministic capital budgeting models (\% per 15 -month flock). ${ }^{1}$

\begin{tabular}{lcc}
\hline Financial output & Conventional & Cage-free \\
\hline MIRR & 20.7 & 5.6 \\
WACC & 9.4 & 9.4 \\
Excess rate of return & 11.3 & -3.8 \\
\hline 1'MIRR, estimated using Equation 2, captures eight 15-month flocks. Cal-Maine Foods Inc.'s WACC (Equation 3) adjusted for a \\
$40 \%$ debt and 60\% equity assumed capital structure, is used to proxy the egg industry opportunity cost of capital.
\end{tabular}

\subsection{Deterministic discounted cash flow valuation}

Cost per hen housed, including investment plus average operating costs during the eight flocks, is about $\$ 35$ more expensive for cage-free production, consistent with industry estimates (Siegner, 2019). EBIT margin, defined as operating profit (i.e. profit before interest and taxes) divided by revenues, is on average $25 \%$ for conventional production and 3\% for cage-free.

Table 3 provides rate of return (MIRR) for both production systems and our estimated opportunity cost of capital (WACC) to benchmark returns. Conventional production is more profitable than cage-free production, yielding $20.7 \%$ rate of return per 15 -months flock compared to $5.6 \%$ per flock for cage-free. ${ }^{9}$

Financial theory states that an excess rate of return $=0$ satisfies debt and equity holders. ${ }^{10}$ Conventional production yields MIRR above WACC, meaning this is a positive net present value enterprise. Conventional production yields 11.3 percentage points above WACC per flock, which serves as a cushion for uncertain inputs negatively affecting profitability. In contrast, cage-free production expected MIRR is below WACC with -3.8 percentage points excess return. These results are driven by the combination of the following differences across production systems: (1) investment for cage-free is $65 \%$ relative to conventional production investment (i.e. relative CAPEX values), but cage-free facilities hold only one fourth of laying hens relative to conventional production; (2) operating costs are $41 \%$ more expensive in cage-free production; and (3) the recent cage-free egg price premia do not offset the additional investment and operating costs in cage-free egg production.

Moreover, compared to conventional production, the cage-free system carries additional production risks such as increased mortality and increased downgraded eggs, and volatile price premium. The effect of volatile production, cost and prices on financial performance is considered next.

\subsection{Stochastic discounted cash flow valuation}

This section discusses DCF model results with the following stochastic variables: (1) conventional egg prices; (2) feed unit cost; (3) cage-free egg price premium; and (4) mortality rates per production system. MIRR statistics of the distributions per production system are shown in Table 4. The last column, 'Portfolio' combines the cash flows of both production systems. This portfolio adds the FCFs of both production systems, representing a farmer producing $81 \%$ conventional and 19\% cage-free eggs, which resembles the current market shares of both products.

As expected, MIRR for cage-free production is lower relative to conventional production. In consequence, having cage-free production in a portfolio reduces profits, on average, from 19.5 to $15.8 \%$ per flock. Further,

\footnotetext{
${ }_{9}^{9}$ Since rates are commonly expressed on a yearly basis, we provide the following approximations: $\mathrm{MIRR}=16.6 \%$ (conventional), $\mathrm{MIRR}=4.4 \%$ (cage-free), and $\mathrm{WACC}=7.5 \%$ (i.e. values approximated by multiplying 15 -month rates times $(12 / 15)$ ).

${ }^{10}$ Surveys to financial executives conducted by Duke University and The CFO Magazine (Graham and Harvey, 2018) suggest that in practice, managers use a hurdle rate (to evaluate projects) that is higher from their calculated WACC by approximately four \% points (with would be equivalent to $5 \%$ on a per flock basis in this application). In this paper we use the estimated WACC as the hurdle rate, but consider this value as a conservative hurdle rate based on this survey results.
} 
Table 4. MIRR for stochastic capital budgeting models (\% per 8,15 -month flock). ${ }^{1}$

\begin{tabular}{llcl}
\hline Item & Conventional & Cage-free & Portfolio \\
\hline Mean (\%) & 19.5 & 8.0 & 15.8 \\
Minimum (\%) & 17.4 & 4.5 & 13.6 \\
Maximum (\%) & 20.9 & 10.4 & 17.4 \\
25\% percentile (\%) & 19.1 & 7.5 & 15.5 \\
$50 \%$ percentile (\%) & 19.5 & 8.1 & 15.9 \\
$75 \%$ percentile (\%) & 19.9 & 8.6 & 16.2 \\
\hline
\end{tabular}

${ }^{1}$ MIRR is estimated using Equation 2. 10,000 simulations were ran with equal seed. Stochastic variables include: (1) conventional egg prices; (2) feed unit cost; (3) cage-free egg price premium; and (4) mortality rates per production system. Assumed distribution and parameters detailed in Section 3.5.

cage-free is below the $9.4 \%$ WACC even at the $75 \%$ percentile, meaning that rate of return of cage-free production would not fully satisfy investors' expectations at the estimated opportunity cost.

Figure 1 shows the distributions of the simulations for conventional production, and Figure 2 for cage-free. There is $90 \%$ probability of obtaining a MIRR between 18.5 and $20.3 \%$ in conventional production. In contrast, in cage-free, there is a $90 \%$ probability of obtaining a MIRR between 6.8 and $9.4 \%$, with only $3 \%$ probability of MIRR exceeding the $9.4 \%$ WACC (i.e. to the right of $9.4 \%$ in Figure 2). The probabilities are shown at the top of the figures. Results from the simulations show that egg production is relatively stable when evaluated on a per flock (or yearly) basis because the high volatility of seasonal monthly prices is smoothed in capital budgeting valuations.

Profitability for cage-free is most sensitive to forecasted egg prices, with the latter being a function of stochastic conventional egg price and a stochastic price premium. Using the stochastic Advanced Analyses / Goal Seek procedure in @RISK ${ }^{\circ}$, we estimated that the cage-free price premium should be, on average, $32 \%$ during the eight flocks, for this project to yield a MIRR $=$ WACC $=9.4 \%$ (i.e. satisfy investors' return expectations). In addition, it is estimated that under the stochastic conditions modeled in this study, a cage-

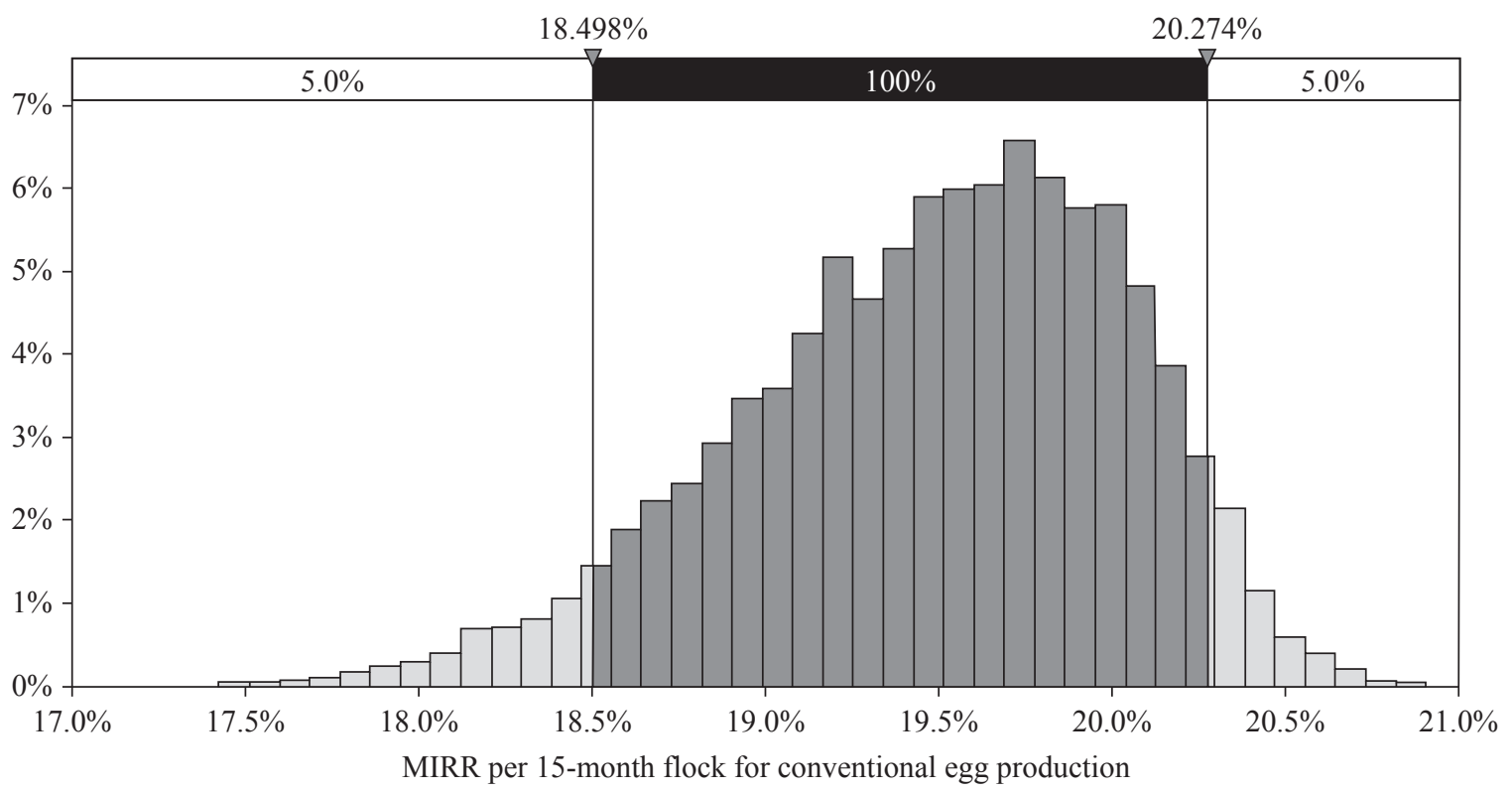

Figure 1. 10,000 simulations with equal seed of MIRR (\% per 15-month flock) for conventional egg production across eight flocks. 


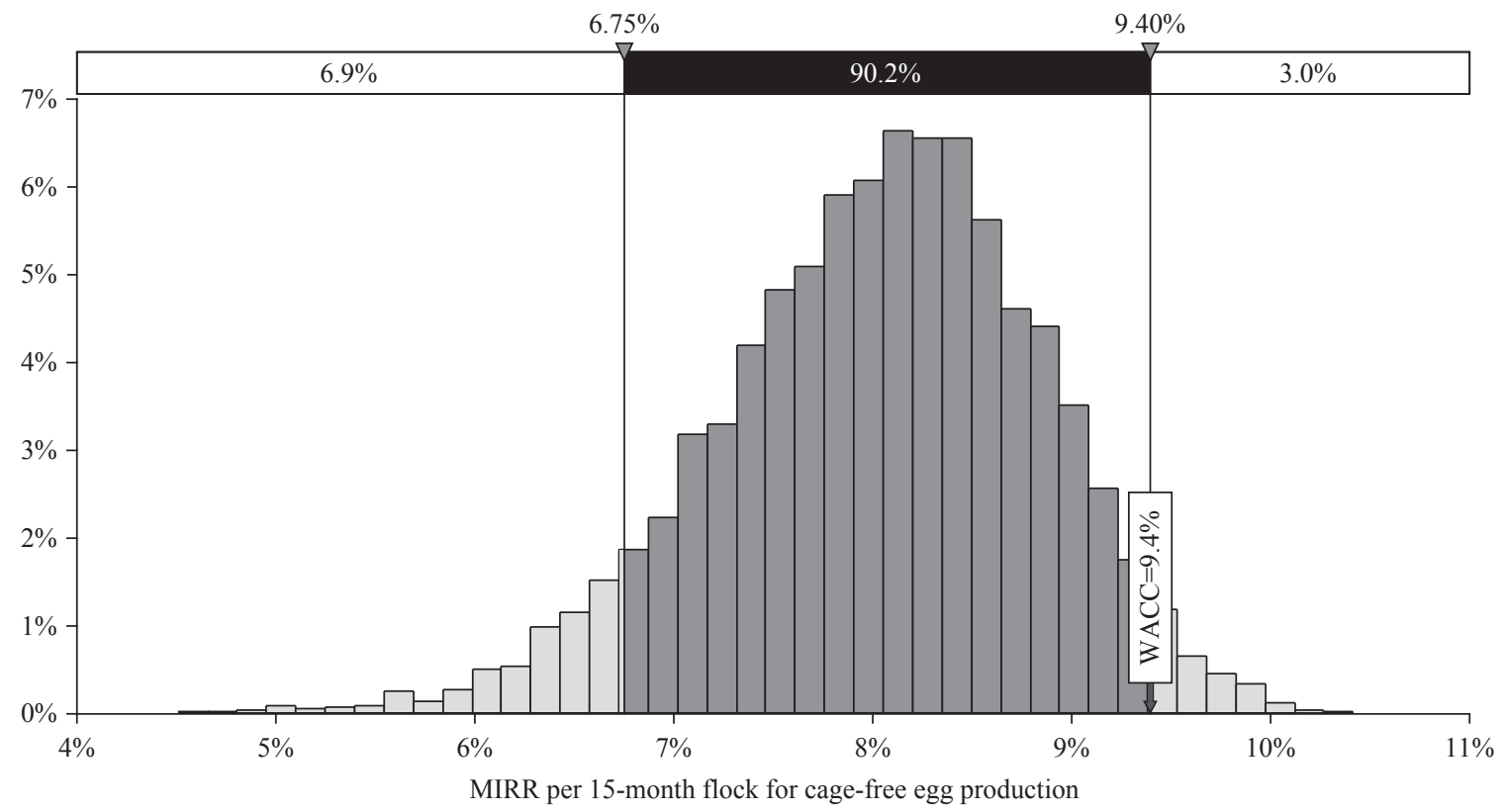

Figure 2. 10,000 simulations with equal seed of MIRR (\% per 15-month flock) for cage-free egg production across eight flocks.

free price premium as high as $74 \%$ is required in order both production systems to be equally profitable, i.e. yield the same MIRR. Such high cage-free egg price premium is highly unlike to occur given recent cage-free premia and consumer willingness to pay estimates from recent research.

Whether the cage-free price premium would increase or decrease in the near future would depend on market pressure from different sources and on what and when US states pass cage-free laws. Customers may not be willing to pay higher prices for cage-free eggs if the niche market for cage-free customers is already saturated. Farmers, on the other side may not be willing to supply additional cage-free eggs absent of higher price premium incentives, given that cage-free production is much less profitable and riskier than conventional production. Profit and risk of egg producers with national market presence may also be affected differently depending on market shares and production locations across the US. It is unclear whether cage-free laws in a particular state will help producers to enjoy rents they would not otherwise obtain or will force producers to exit the market in that particular state (Mullally and Lusk, 2018).

Thus, it is difficult to predict the effect these nascent cage-free laws in the US would have on conventional and cage-free prices. In the mid-term, as cage-free laws are implemented and major food buyers meet their cage-free purchases goals, ex-post price analyses should provide predictions. Our study, however, provides a framework for egg farm managers and the government to analyze management strategies to cope with as farmers transition to an uncertain cage-free eggs market. For instance, egg farmers will likely manage a portfolio of both conventional and cage-free production in the mid-term. Using the framework in this study, the egg producer can evaluate the potential effect on profits (and consequently, on decisions related to financing and investment policies) of changing the mix of their portfolio. This is particularly important in instances on which a farm's specific profitability do not meet producers' return and risk expectations, but where participating in this nascent market would be a necessity to continue in the industry.

\section{Conclusions}

Consumer driven changes in meat and egg production can have lasting effects. California passing a second law that directs how table eggs are to be produced shows that this trend is gaining steam. Other states such as Oregon have already begun to consider passing cage-free laws. From the producer's perspective this shows 
an interest in changing production practices and an indication for substantial layer house modifications in order to comply or meet consumer demands. Transitioning from conventional to cage-free production is expensive though. Establishing a cage-free system requires additional investments to conform to cage-free laws, increases operational costs due to changes in production practices, and increases marketing risk by making more uncertain demand and price prediction. This study compares profitability and risk of conventional and cage-free egg production over eight flocks using production practices, cost and investment structure budgets in the literature and forecasted feed and output prices.

This study contributes to the nascent literature on cage-free production in several ways. First, we update Matthews and Summer' (2015) cost and investment egg production budgets, which documented the first systematic comparison of investment and operating costs across egg housing systems by one US commercial farm using the same management and accounting practices. Our study updates certain items from the budget, notably feed and pullet cost. This budget update is necessary given that Matthews and Summer's study was conducted in 2010/2011, when commodity prices affecting feed and pullet prices, were extraordinarily high relative to current and projected prices. Second, we apply DCF to value both conventional and cagefree enterprises over a long-term business horizon, which is needed to evaluate profitability of a poultry investment. The DCF model has incorporated 2020-2029 forecasted conventional egg prices by USDA Office of the Chief Economist, and cage-free price premium projections based on recent historical data from the Egg Industry Center. Rates of return of conventional and cage-free investments are compared to an estimated opportunity cost of capital. We also apply stochastic simulation to incorporate uncertainty to the analysis. Our estimations are presumably for a representative medium-sized poultry farm that sells either conventional or cage-free eggs.

Findings in this study indicate that cage-free production yields by far a lower expected rate of return than conventional production, and is riskier. Stochastic simulation shows that profitability return, measured by the MIRR, for conventional production is above an estimated industry opportunity cost of capital, measured by the WACC. In contrast, MIRR for cage-free is below the WACC, meaning that the rate of return of cage-free production would not fully satisfy investors' expectations at the estimated opportunity cost. The rate of return of cage-free investment, between 5.6\% (deterministic model) and 8.0\% (stochastic) per 15-month flock, is below the estimated $9.4 \%$ opportunity cost of capital. In addition, the simulations show that there is a $90 \%$ probability of conventional production's MIRR falling between 18.5 and $20.3 \%$ per 15 -month flock, and cage-free egg production's MIRR ranging from 6.8 to $9.4 \%$. In order for cage-free to be as equally profitable as conventional production, cage-free egg prices at the farmer gate should be $74 \%$ over conventional egg prices. Such high cage-free egg prices are highly unlikely to occur given recent cage-free price premia and consumer willingness to pay estimates from recent research.

Our overall finding in this study is consistent with anecdotal evidence suggesting that some farmers who started to produce cage-free in Tennessee, US switched back to conventional production after realizing that cage-free production was not as economically attractive as conventional production. At a greater scale, CalMaine Foods Inc., the egg producer company with the largest market share in the US, announced in its 2019 Annual Report to shareholders that the firm anticipates increasing operating costs and additional investments to meet anticipated demand for cage-free eggs from its major customers, including food service providers, national restaurant chains, and major retailers, who have already stated future dates to exclusively offer cagefree eggs. As firms increase the portion of cage-free egg in their portfolio of products in the following years, decreasing firm profits may induce firms to increase retail egg prices and negatively affect consumers. With the changing food production environment driven by consumer demanding particular production practices, this work provides an avenue of discussion on the feasibility and financial prospects of converting to a cage-free system in the US egg layer industry. Egg producers can use the models proposed in this study to evaluate the potential effects of changes in their portfolio of products (i.e. conventional and cage-free mix) as they accommodate production schedules in this evolving industry. 


\section{Supplementary material}

Supplementary material can be found online at https://doi.org/10.22434/IFAMR2020.0046

Table S1. Timeline of planned activities.

\section{Funding}

This work was partially supported by the USDA National Institute of Food and Agriculture, Hatch MultiState project 1020537.

\section{References}

Aerni, V., M.W.G. Brinkhof, B. Wechsler, H. Oester and E. Fröhlich. 2005. Productivity and mortality of laying hens in aviaries: a systematic review. World's Poultry Science Journal 61(1): 130-142. https:// doi.org/10/cv7x2c

Agralytica Consulting. 2012. Economic impacts of converting US egg production to enriched cage systems - a report for United Egg producers. Agralytica Consulting, Alexandria, VA, USA.

Bell, D.D. and W.D. Weaver (eds.). 2002. Commercial chicken meat and egg production, $5^{\text {th }}$ edition. Springer, New York, NY, USA. Available at: https://www.springer.com/gp/book/9780792372004

Bir, C., N.M. Thompson, W.E. Tyner, J. Hu and N.J.O. Widmar. 2018. 'Cracking' into the debate about laying hen housing. Poultry Science 97(5): 1595-1604. https://doi.org/10.3382/ps/pey017

Bovay, J. and D. Summer. 2019. Animal welfare, ideology, and political labels: evidence from California's proposition 2 and Massachusetts's question 3. Journal of Agricultural and Resource Economics 44(22): 246-266. https://doi.org/10.22004/ag.econ.287970

Brigham, E.F. and J.F. Houston. 2019. Fundamentals of financial management, $10^{\text {th }}$ edition. Cengage Learning Inc., Boston, MA, USA.

Burch, D.G. 2012. Laying hen mortality by system - a welfare guide? Veterinary Record 171(25): 649-650. https://doi.org/10.1136/vr.e8582

Cal-Maine Foods. 2019a. Form 8-K reported on January 4, 2019 by Cal-Maine Foods, Inc. to the Securities and Exchange Commission. Cal-Maine Foods, Jackson, MS, USA. Available at: http://www.calmainefoods. com/investors/sec-filings/

Cal-Maine Foods. 2019b. Form 10-K Reported on July 22, 2019 by Cal-Maine Foods, Inc. to the Securities and Exchange Commission. Cal-Maine Foods, Jackson, MS, USA. Available at: http://www.calmainefoods. com/investors/sec-filings/

Coalition for Sustainable Eggs Supply (CSES). 2015. Laying hen housing research project. CSES, Gladstone, MO, USA. Available at: http://www2.sustainableeggcoalition.org/final-results

Egg Industry Center (EIC). 2019. U.S. flock trends and projections. Egg Industry Center, Ames, IA, USA, pp. 1-19. Available at: https://www.eggindustrycenter.org/industry-analysis/ categories/15de6a876f6348ef8fe28e9ed5827163

Egg Industry Center (EIC). 2020. Industry analysis. Cost and prices reports. Egg Industry Center, Ames, IA, USA. Available at: https:/www.eggindustrycenter.org/industry-analysis/categories/ 26b2be3f446d4e56b0c72b587c4058ee

Elson, A. 2008. Do extensive poultry systems really offer superior welfare? Poultry Welfare, Rockford, IL, USA. Available at: https://www.wattagnet.com/articles/3204-do-extensive-poultry-systems-reallyoffer-superior-welfare

Fossum, O., D.S. Jansson, P.E. Etterlin and I. Vågsholm. 2009. Causes of mortality in laying hens in different housing systems in 2001 to 2004. Acta Veterinaria Scandinavica 51(3): 1-9. https://doi.org/10/cw9gdm

Graham, J. and C. Harvey. 2018. The equity risk premium in 2018. Social Science Research Network, Rochester, NY, USA. https://doi.org/10.2139/ssrn.3151162 
Holt, P.S., R.H. Davies, J. Dewulf, R.K. Gast, J.K. Huwe, D.R. Jones, D. Waltman, and K.R. Willian. 2011. The impact of different housing systems on egg safety and quality. Poultry Science 90(1): 251-262. https://doi.org/10/b95gw5

Ibarburu, M. 2017. U.S. egg cost of production and prices. Egg Industry Center, Ames, IA, USA, pp. 1-12. Available at: https://www.eggindustrycenter.org/industry-analysis

Ibarburu, M. 2019. U.S. egg cost of production and prices. Egg Industry Center, Ames, IA, USA, pp. 1-12. Available at: https://www.eggindustrycenter.org/industry-analysis

Ibarburu, M. and D. Bell. 2014. U.S. and regional estimates of layer feed prices, cost of producing eggs and egg prices. Egg Industry Center, Ames, IA, USA, pp. 48. Available at: http://www.ans.iastate.edu/ EIC/newsletters/LayerFeb2014.pdf

Jagannathan, R., D. Matsa, I. Meier and V. Tarhan. 2016. Why do firms use high discount rates? Journal of Financial Economics 120(3): 445-463. https://doi.org/10.1016/j.jfineco.2016.01.012

Karcher, D.M., D.R. Jones, Z. Abdo, Y. Zhao, T.A. Shepherd and H. Xin. 2015. Impact of commercial housing systems and nutrient and energy intake on laying hen performance and egg quality parameters. Poultry Science 94(3): 485-501. https://doi.org/10/f65bdq

Keller and Heckman LLC. 2018. California's proposition 12 animal welfare measure wins big - requires cage-free eggs by 2022. National Law Review 8: 332. Available at: https://www.natlawreview.com/ article/california-s-proposition-12-animal-welfare-measure-wins-big-requires-cage-free-eggs

Kenner, B., D. Lambert, C. Trejo-Pech, J. Thompson and T. Gill. 2019. Financial risks in Rwandan smallholder broiler production. Journal of Agribusiness in Developing and Emerging Economies 9(5): 569-83. https://doi.org/10.1108/JADEE-11-2018-0163

Kierulff, H. 2008. MIRR: a better measure. Business Horizons 51: 321-329. https://doi.org/10.1016/j. bushor.2008.02.005

KPMG. 2018. Corporate tax rates table. KPMG, Amstelveen, the Netherlands. Available at: https://home. $\mathrm{kpmg} / \mathrm{xx} / \mathrm{en} / \mathrm{home} /$ services/tax/tax-tools-and-resources/tax-rates-online/corporate-tax-rates-table.html

Lusk, J. 2019. Consumer preferences for cage-free eggs and impacts of retailer pledges. Agribusiness: an International Journal 35(2): 129-148. https://doi.org/10.1002/agr.21580

Lusk, J.L. and F.B. Norwood. 2011. Animal welfare economics. Applied Economic Perspectives and Policy 33(4): 463-483. https://doi.org/10.1093/aepp/ppr036

Macrotrends. 2019. Corn prices - 45 year historical chart. Macrotrends. Available at: https://www.macrotrends. net/2532/corn-prices-historical-chart-data

Madigan, J. 2019. Cracked up: rising egg consumption will be offset by declining egg prices. IBIS World Industry Report 11231, IBIS World, New York, NY, USA, 39 pp. Available at: http:/tinyurl.com/ yb5aa6do

Matthews, W.A. and D.A Summer. 2015. Effects of housing system on the costs of commercial egg production. Poultry Science 94(3): 552-557. https://doi.org/10.3382/ps/peu011

Morris, C. 2016. USDA graded cage-free eggs: all they're cracked up to be. U.S. Department of Agriculture, Washington, DC, USA. Available at: https://www.usda.gov/media/blog/2016/09/13/usda-gradedcage-free-eggs-all-theyre-cracked-be

Mullally, C. and J.L. Lusk. 2018. The impact of farm animal housing restrictions on egg prices, consumer welfare, and production in California. American Journal of Agricultural Economics 100(3): 649-669. https://doi.org/10.1093/ajae/aax049

Palisade. 2018. @Risk: risk analysis and simulation add-in for Microsoft Excel. Palisade Corporation, Ithaca, NY, USA. Available at: https://www.palisade.com/risk/

Pershan, C. 2018. CA voters pass cage-free egg proposition with consequences for veal and pork. EATER. Available at: https://sf.eater.com/2018/11/7/18072268/eggs-cage-free-hens-proposition-12-californiapassed-approved

Promar International. 2009. Impacts of banning cage egg production in the United States - a report for United Egg Producers. Promar International, Alexandria, VA, USA. Available at: https://www.readkong. com/page/impacts-of-banning-cage-egg-production-in-the-united-states-3065360

Rees, M. 2015. Business risk and simulation modelling in practice. Wiley Finance Series, West Sussex, UK. 
Rodenburg, T., F. Tuyttens, K. de Reu, L. Herman, J. Zoons and B. Sonck. 2008. Welfare assessment of laying hens in furnished cages and non-cage systems: assimilating expert opinion. Animal Welfare 17(4): 355-361.

Schill, M.J. 2017. Business valuation: standard approaches and applications. Darden Business Publishing, University of Virginia, Charlottesville, VA, USA, 14 pp.

Sharpe, W.F. 1964. Capital asset prices: a theory of market equilibrium under conditions of risk. The Journal of Finance 19: 425-442.

Siegner, C. 2019. Cage-free egg commitments are in the spotlight - and may cost companies billions. Food Dive, March 13. Available at: https://www.fooddive.com/news/cage-free-egg-commitments-are-inthe-spotlight-and-may-cost-companies-bil/550246/

S\&P Capital IQ. 2020. Standard \& Poor's NetAdvantage: S\&P Capital IQ Database. S\&P Global Market Intelligence, New York, NY, USA.

Summer, D.A., H. Gow, D. Hayes, W. Matthews, B. Norwood, J. Rosen-Molina and W. Thurman. 2011. Economic and market issues on the sustainability of egg production in the United States: analysis of alternative production systems. Poultry Science 90(1): 241-250. https://doi.org/doi.org/10.3382/ ps.2010-00822

Sumner, D.A, J.T. Rosen-Molina, W.A. Matthews, J.A. Mench and K.R. Richter. 2008. Economic effects of proposed restrictions on egg-laying hen housing in California. University of California Agricultural Issues Center, Davis, CA, USA, 115 pp. Available at: https://aic.ucdavis.edu/publications/eggs/ egginitiative.pdf

Trejo-Pech, C., T. Spreen and M. Zansler. 2018. Is growing oranges in Florida a good investment? American Journal of Agricultural Economics 100(2): 625-639. https://doi.org/10.1093/ajae/aax107

Trejo-Pech, C., R. Weldon and M.A. Gunderson. 2016. Earnings management through specific accruals and discretionary expenses: evidence from U.S. agribusiness firms. Canadian Journal of Agricultural Economics 64(1): 89-118. https://doi.org/doi.org/10.1111/cjag.12063

Trejo-Pech, C. and S. White. 2020. Capital budgeting analysis of a vertically integrated egg firm: conventional and cage-free egg production. Applied Economics Teaching Resources 2: 1-13.

Turvey, C., X. Gao, R. Nie, L. Wang and R. Kong. 2013. Subjective risks, objective risks and the crop insurance problem in rural China. The Geneva Papers on Risk and Insurance - Issues and Practice 38(3): 612-633. https://doi.org/10.1057/gpp.2012.42

United Egg Producers. 2017. Animal husbandry guidelines for U.S. egg-laying flocks. Guidelines for cagefree housing. United Egg Producers, Johns Creek, GA, USA. Available at: https://uepcertified.com/ wp-content/uploads/2019/09/CF-UEP-Guidelines_17-3.pdf

U.S. Department of Labor, Bureau of Labor Statistics. 2020. Daily treasury long term rate data. U.S. Department of Labor, Washington, DC, USA. Available at: https:/www.bls.gov/cpi/

U.S. Department of the Treasury. 2020. Daily treasury long term rate data. US Department of the Treasury, Washington, DC, USA. Available at: https://www.treasury.gov/resource-center/data-chart-center/ interest-rates/Pages/TextView.aspx?data=longtermrateYear\&year $=2019$

USDA Agricultural Marketing Service (USDA-AMS). 2020a. Monthly USDA cage-free shell egg report. USDA AMS, Washington, DC, USA. Available at: https://www.ams.usda.gov/market-news/eggmarket-news-reports

USDA Agricultural Marketing Service (USDA-AMS). 2020b. Monthly USDA cage-free shell egg reportfor the month of December 2019. USDA Agricultural Marketing Service, Washington, DC, USA. Available at: https://downloads.usda.library.cornell.edu/usda-esmis/files/rj4304553/xg94j533q/ vd66wf94k/PYMCAGEFREE.PDF

USDA, National Agricultural Statistics Service. 2019. Chickens and eggs 1948-9064. U.S. Department of Agriculture, Washington, DC, USA. Available at: https://usda.library.cornell.edu/concern/publications/ fb494842n?locale $=$ en

USDA Office of the Chief Economist. 2020. USDA agricultural projections to 2029. U.S. Department of Agriculture, Washington, DC, USA. Available at: https://www.usda.gov/oce/commodity/projections/ USDA_Agricultural_Projections_to_2029.pdf 
Van Staaveren, N., C. Decina, C. Baes, T. Widowski, O. Berke and A. Harlander-Matauschek. 2018. A description of laying hen husbandry and management practices in Canada. Animals 8(7): 114. https://doi.org/10.3390/ani8070114

Weeks, C.A., S.N. Brown, G.J. Richards, L.J. Wilkins and T.G. Knowles. 2012. Levels of mortality in hens by end of lay on farm and in transit to slaughter in Great Britain. Veterinary Record 170(25): 647-650. https://doi. org/10.1136/vr.100728

Welshans, K. 2018. Potential for cage-free eggs to attain majority market share unlikely. Feedstuffs, May 4. Available at: https://www.feedstuffs.com/news/study-potential-cage-free-eggs-attain-majority-market-share-unlikely

Yeboah, A., C. Naanwaab, O. Yeboah, J. Owens and J. Bynum. 2013. Economic feasibility of sustainable high oilseedbased biofuel production: the case for biodiesel in North Carolina. International Food and Agribusiness Management Review 16(1): 41-66. 